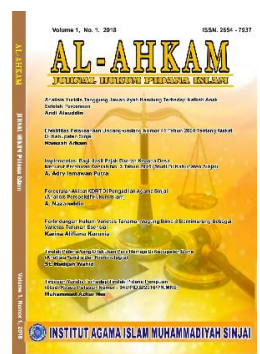

Al-Ahkam

Jurnal Hukum Pidana Islam

Volume 2, No. 2, 2020

ISSN (print) : 2654-7937

ISSN (online) : 2715-0313

Homepage : http://journal.iaimsinjai.ac.id/index.php/al-ahkam/index

\title{
SENGKETA BATAS WILAYAH INDONESIA DAN MALAYSIA STUDI KASUS PULAU SEBATIK DALAM PERSPEKTIF HUKUM TATA NEGARA
}

\author{
Siti Febrianti' ${ }^{1}$ Farin Nur Azizah ${ }^{2}$, Depict Pristine Adi ${ }^{3}$ \\ ${ }^{I}$ IAIN Jember, Jl Mataram No 1 Karang Miuwo Mangli, Jember \\ ${ }^{2}$ IAIN Jember, Jl Mataram No 1 Karang Miuwo Mangli, Jember \\ ${ }^{3}$ IAIN Jember, Jl Mataram No 1 Karang Miuwo Mangli, Jember \\ E-mail: febryan210298@gmail.com.Tlp083846860082
}

\begin{abstract}
Abstrak
Tujuan dari penelitian ini yaitu untuk mengetahui tentang sengketa batas wilayah antara Indonesia dan Malaysia dalam studi kasus pulau sebatik. Dalam penelitian in imembahas mengenai persengketaan antara Indonesia dan Malaysia sudah terjadi sejak tahun 1967 yang berawal dari persengketaan pulau sipadan dan ligitan yang hingga sampai tahun 2019 negara Indonesia dan Malaysia.Metode yang di gunakan dalam penelitian ini adalah metode kepustakaan yaitu tehnik pengumpulan data dengan melakukan penelaah terhadap berbagai buku, litetur, catatan, serta berbagai laporan yang berkaitan dengan masalah yang ingin di pecahkan. Berdasarkan hasil pembahasan dapat disimpulkan bahwa sengketa batas wilayah Indonesia dan Malaysia di Pulau Sebatik diawali dengan konflik pulau sipadan dan ligitan, yang berimbas pada adanya konflik pulau sebatik namun hingga saat ini konflik tersebut belum menemukan titik terang untuk penyelesaian konflik, hanya saja upaya yang dilakukan terjadi pada tahun 2019 dengan adanya pembuatan patokan perbatasan baru di Kecamatan Sebatik, Kabupaten Nunukan, Kalimantan Utara.
\end{abstract}

Kata kunci : sengketa, batas wilayah, pulau sebatik

\section{Abstrak}

The purpose of this study is to find out about territorial disputes between Indonesia and Malaysia in the Sebatik Island case study. In this research, discussing about disputes between Indonesia and Malaysia has been going on since 1967, which began with the disputes of the islands of Sipadan and Ligitan, which until until 2019 Indonesia and Malaysia., notes and various reports relating to the problem you want to solve. Based on the results of the discussion it can be concluded that the disputes over the boundaries of Indonesia and Malaysia on the Sebatik Island began with the conflicts of the islands of Sipadan and Ligitan, which impacted on the existence of the conflict of the Sebatik islands but until now the conflict has not found a bright spot for conflict resolution, only the efforts made have taken place. in 2019 with the creation of a new border benchmark in Sebatik District, Nunukan Regency, North Kalimantan.

Keywords: disputes, territorial boundaries, sebatik island 


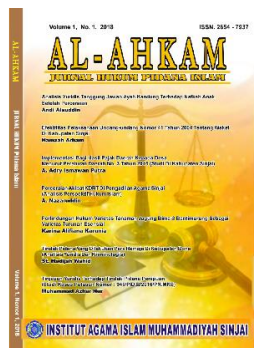

\section{Pendahuluan}

Batas wilayah suatu negara menempati posisi paling penting yang dilihat dari aspek geografis, hukum, maupun politis. Secara geografis, batas wilayah suatu negara meliputi daratan, lautan dan udara yang ada diatasnya. Secara hukum, batas wilayah suatu negara menentukan ruang lingkup berlakunya hukum nasional suatu negaera tersebut. Sedangkan secara politik, batas wilayah merupakan akhir dari jangkauan kekuasan tertinggi yang meliputi sesuatu yang ada di dalam wilayah tersebut. ( Budi Hermawan, 2017: 52)

Menurut Undang-undang nomor 43 tahun 2008 tentang wilayah Negara,mengatur tentang batas wilayah Negara. Batas wilayah Negara berada pada di darat, perairan, dasar laut dan tanah di bawahnya serta ruang udara diatasnya ditetapkan atas dasar perjanjian bilateral dan trilateral mengenai batas darat, batas laut, dan batas udara sertaberdasarkanperaturan perundang-undangan dan hukum Internasional.(Mexsasai, 2013: 13). Didalam undang-undang tersebut juga dijelaskan mengenai wilayah yurisdiksi dan batas wilayah yurisdiksi. Wilayah yurisdiksi adalah wilayah diluar wilayah Negara yang terdiri atas zona ekonomi eksklusif (ZEE) dan wilayah batas yurisdiksi adalah garis batas yang merupakan pemisah hak berdaulat dan kewenangan tertentu yang dimilik oleh Negara yang didasrkan atas ketentuan peraturan perundang-undangan dan hukum internasional. Dalam menentukan batas wilayah memiliki berberapa cara yang dapat dilakukan yaitu dengan cara perundingan, diplomasi, serta ,mencari dukungan kepada Negara maju dan dengan dicetusnya laut territorial 12 mil dari pulau terluar Indonesia untuk mencegah disintegrasi bangsa dan mempertahankan persatuan dan kesatuan.Dalam menentukan tapal batas suatu wilayah atau Negara dapat memicu terjadinya konflik , yang dapat menyebabkan hubungan antar Negara mengalami konflik sosial. Hal tersebut memiliki banyak factor penyebab diantaranya rendahnya tinggkat kesejahteraan masyarakat, yang tinggal di wilayah perbatasan, tidak adanya batasan fisik yang jelas yang dibangun untuk menunjukkan garis batas wilayah antar Negara, jumlah petugas yang menjaga kawasan perbatasan masih belum memadai. (Musyridyamsyah : 2017)

Kawasan perbatasan negara merupakan manifestasi utama dalam kedaulatan suatu negara. Kawasan perbatasan suatu negara memiliki peranan yang begitu penting seperti dalam penentuan batas wilayah kedaulatan, pemanfaatan sumber daya alam, serta keamanan dan keutuhan suatu wilayah di negara. (Budi Hermawan, 2017 : 53) Kawasan perbatasan merupakan kawasan yang rawan menyangkut hubungan antar negara. Persoalan yang sering terjadi di kawasan perbatasan adalah persoalan garis batas itu sendiri, yaitu kedua belah pihak yang ingin menggeser patokan perbatasan antar negara. Banyak sekali negara di dunia ini yang berkeinginan untuk memperluas wilayah teritori mereka, karena hal tersebut menyangkut gengsi sebuah negara yang beranggapan semakin luas negara maka akan dianggap akan semakin kuat negara tersebut, serta menyangkut eksplorasi sumber daya alam. ( Robert Siburian, 2012:55)

Kawasan wilayah perbatasan mulai menjadi perhataian setiap pemerntah yang wilyah negranya secara langsung berbatasan dengan negara lain. Kesadaran akan adanya persepsi wilayah perbatasan antar negara telah mndorong para biroktrat dan perumus keebijaakan untuk mengembangkan suatuu kajian tentaang penataan wilayah perbatasan yang teah dilengkapi dengan perumusan sistem keamanannya. Hal tersebut menjadi isu strategis karna penataan kawasan perbatasan terkait dengan proses nation state building terhadap kebunculan potensi konflik internal di suatu negara bahkan juga terhadap negara lainnya (neighbourhood countries). Penanganan suatu perbatasan antar negara merupakan bagian dari upaya perwujudan ruang wilayah nusantara sebagai suatu kesatuan dari 


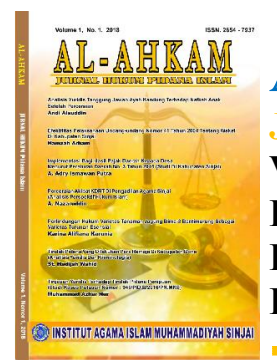

Al-Ahkam

Jurnal Hukum Pidana Islam

Volume 2, No. 2, 2020

ISSN (print) : 2654-7937

ISSN (online) : 2715-0313

Homepage : http://journal.iaimsinjai.ac.id/index.php/al-ahkam/index

geografi, politik, ekonomi, sosial budaya dan pertahanan keamanan. ( Zulkifli Rahmat, $2014: 3386$ )

Salah satu kasus mengenai perbatasan wilayah adalah kasus pulau Sebatik. Kasus tersebut merupakan kasus turunan dari kasus pulau SipadandanLigitan yang terjadipadatahun 1967 antara Negara Indonesia dan Malaysia. Pulau Sebatik sendiri adalah sebuah pulau kecil yang berada di Provinsi baru yakni Kalimantan Utara, tepatnya masuk ke dalam wilayah Kabupaten Nunukan. Secara administratif pulau ini dimiliki oleh dua negara yang berbeda, yang dibelah oleh sebuah garis lurus yang merupakan perbatasan antar negara. Pulau Sebatik bagian Selatan di kuasai oleh Negara Indonesia sedangkan bagian Utara dikuasai oleh Negara Malaysia. ( Purnawan Basundoro, 2013 : 134 ).Pulau Sebatik terbagi atas dua wilayah yaitu Sebatik wilayah Malaysia dibagian utara dan Sebatik wilayah Indonesia di bagian Selatan, dengan jumlah penduduk sekitar 25000 orang di Seabtik wilayah Malaysia dan 80000 orang di Sebatik wilayah Indonesia. Pulau ini berda di ujung utara Kalimantan timur dengan luas hanya 246,61 km².(Mayor Inf Hasan Abdullah, 2013 : 84). Yang mendasari terjadinya konflik sebatik yaitu perbedaan koordinat antara garis batas yang ditentukan dengan menggunakan tehnologi dulu dan sekarang. Terlebih lagi dari belasan pilar yang menandai perbatasan Indonesia dan Malaysia beberapa sudah hilang termasuk pilar paling barat.

Ketidak jelasan perbatasan kedua negara tersebut merupakan sebuah penghambat atas perkembangan daerah perbatasan. Hal itu sesuai dengan peraturan pemerintah yang mengatakan bahwa uang negara tidak dapat di gunakan untuk membangun daerah yang kepemilikannya belum jelas. Yang berdampak pada kondisi ekonomi di pulau sebatik bagian Indonesia. Menurut Dr. Kosasih ( $2015: 21$ ) diperlukan sebuah pendekatan teknis dan politis untuk mempercepat penyelesaian konflik tersebut.

Upaya pemerintah dalam menaggulangi kasus ini salah satunya yaitu melakukan renacana pembangunan jangka panjang dan rencana pembangunan jangka menengah. Karena Perbatasan merupakan kawasan strategis yang letaknya secara langsung berhadapan dengan wilayah negara lainnya.(Sonny Sudiar ,2012 : 395) Dengan adanya upaya pemerintah ini diharpkan dapat mengatasi permasalahan yang terjadi di kawasan perbatasan antara Indonesia dan Malaysia.

Berdasarkan penjelasan di atas penulis mengangkat judul " Sengketa batas wilayah Indonesia dan Malaysia studi kasus pulau Sebatik dalam prespektif hukum tata negara".

Berdasarkan latar belakang tersebut dapat dirumuskan rumusan masalah sebagai berikut " bagaimana sengketa btas wilayah Indonesia dan Malaysia studi kasus pulau Sebatik dalam prespektif hukum tata negara ?"

untuk Dengan tujuan penulisan dalam jurnal ini sebagai berikut : mengetahui bagaimana sengketa btas wilayah Indonesia dan Malaysia studi kasus pulau Sebatik dalam prespektif hukum tata negara.

\section{Metode}

Peneliti menggunakan metode penelitian dengan jenis kajian kepustakaan. metode kepustakaan yaitu tehnik pengumpulan data dengan melakukan penelaah terhadap berbagai buku, litetur, catatan, serta berbagai laporan yang berkaitan dengan masalah yang ingin di pecahkan. ( Mestika Zed, $2008: 3$ )

\section{Hasil dan pembahasan}

Hasil dari kajian kepustakaan yang di peroleh sebagai berikut: Kepulauan tersebut terbagi menjadi dua dan dimiiki oleh dua Negara, yaitu Indonesia dan Malaysia dan di huni oleh etnis dengan Budaya yang sama, yaitu Budaya Melayu. Dan terdapat beberapa rumah yang badan rumahnya terletak di dua wilayah Negara.Bagian depan 


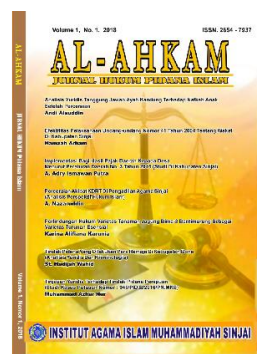

Al-Ahkam

Jurnall Hukum Pidana Islam

Volume 2, No. 2, 2020

ISSN (print) : 2654-7937

ISSN (online) : 2715-0313

Homepage : http://journal.iaimsinjai.ac.id/index.php/al-ahkam/index

masuk ke wilayah Indonesia dan bagian belakang masuk ke wilayah Malaysia ( Purnawan Basundono, 2013 : 135 ). Pulau sebatik luasnya ialah 433,84 $\mathrm{km}^{2}$. Pulau tersebut berada di dua wilayah negara yaitu bagian utara Sebatik termasuk kedalam wilayah milik Malaysia yang luasnya $187,23 \mathrm{~km}^{2}$, dan bagian selatan pulau ini adalah milik Indonesia dengan luassekitar $246,61 \mathrm{~km}^{2}$. Sengketa wilayah sebatik berawal dari adanya kasus sipadan dan ligitan yang kemudian dilanjutkan oleh kasus ambalat ( Chairil, dkk, 2019 : 29 ).

Sebelum kita membahas hasil dari hasil kajian kepustakaan, peneliti akan menguraikan mengenai konsepsi wilayah perbatasan Negara. Perbatasan sebuah Negara atau state's border, yang dikenal secara langsung bersamaan dengan lahirnya sebuah Negara. Negara dalam pengertian modern sudah deikenal sejka abad ke- 18 di Eropa. Perbatasan Negara merupakan sebuah ruang geografis yang sejak awal nerupakan wilayah perebutan kekuasaan antar Negara, yang ditandai oleh adanya pertarungan untuk memperluas batas - batas anatara sesame Negara. Kawasan perbatasan Negara merupakan pengaktualan utama kedaulatan wilayah dalam suatu Negara. Kawasan suatu Negara memiliki peranan yang sangat penting seperti dalam menentukan batas wilayah kedaulatan, pemanfaatan sumber daya alam, serta keamanan dan keutuhan wilayah. Dalam permasalahan perbatasan memiliki dimensi yang sangat kompleks. Terdapat bebrapa faktor krusial yang terkait dengan permasalahan tersebut seperti yuridiksi dan kedaulatan Negara, politik, sosial ekonomi, dan pertahanan keamanan. Pengertian perbatasan menurut alhi geografi politik, perbatasan dapat dibedakan menjdi dua yaitu boundary dan frontier. Boundary digunakan krena fungsinya yang mengokat atau mmbatsi (bound or limit) Negara sebagai suatu unit spasial politik yang berdaulat, sedangkan frontier digunkn untuk menyebut perbatasan karena posisinya yang trletak di depam (front) atau dibelkang (hinterland) dari suatu Negara. Dari pengertian keduanya meskipun memiliki perbedaan namun keduanya memiliki keterkaitan yang sangat erat yang saling melengkapi dan mempunyai nilai yang strategis bagi kedaulatan wilayah Negara. (Budi Hermawan Bangun, $2016: 53$ )

Berdasarkan penjelasan hasil pertama, maka peneliti melakukan analisis sebagai berikut: Permasalahan terkait Perbatasan Pulau Sebatik yang hingga detik ini masih banyak menimbulkan pertanyaan dan bahkan masih banyak isu yang bermunculan, salah satu dari permasalahan Pulau Sebatik ini ialah terkait tentang Perbatasan Pulau sebatik yang sangat unik. Mengapa sangat unik? Karena kepulauan tersebut dimiliki oleh 2 negara yaitu Indonesia dan Malaysia dan di huni oleh etnis dengan Budaya yang sama, yaitu Budaya Melayu.Dan terdapat beberapa rumah yang badan rumahnya terletak di dua wilayah Negara. Bagian depan masuk ke wilayah Indonesia dan bagian belakang masuk ke wilayah Malaysia ( Purnawan Basundono, 2013 : 135 ). Pulau sebatik luasnya ialah $433,84 \mathrm{~km}^{2}$. Pulau tersebut

berada di dua wilayah negara yaitu bagian utara Sebatik termasuk kedalam wilayah milik Malaysia yang luasnya $187,23 \mathrm{~km}^{2}$, dan bagian selatan pulau ini adalah milik Indonesia dengan luassekitar 246,61 km². ( Chairil, dkk, $2019: 29$ ). Kemudian melihat dari segi history pada tahun 1967 bermula dari adanya kasus Pulau Sipadan dan Ligitan yang dipicu dari kedua negara mengadakan perundingan untuk menetapkan batas landas kontinen. Pada saat itulah terjadi perdebatan yang sehubungan dengan kepemilikan pulau Sipadan dan Ligitan. dimana terjadi sebuah perjanjian antara Hindia Belanda dan Inggris tentang kepemilikan batas wilayah keduanya yang berawal ketika Indonesia dan Malaysia merundingkan Delimitasi batas Maritim antara keduanya di laut Sulawesi. Dengan diadakan forum oleh Mahkamah Internasional dan berbagai pertimbangan yang dilakukan maka pulau Sipadan dan Ligitan jatuh kepada negara Malaysia. Selepas 


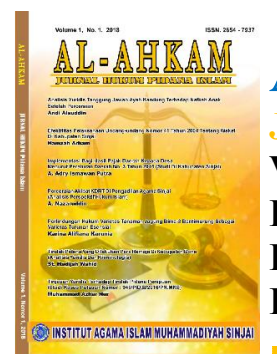

Al-Ahkam

Jurnal Hukum Pidana Islam

Volume 2, No. 2, 2020

ISSN (print) : 2654-7937

ISSN (online) : 2715-0313

Homepage : http://journal.iaimsinjai.ac.id/index.php/al-ahkam/index

permasalahan sengketa sipadan dan ligitan, disusul dengan adanya kasus sengketa ambalat, kasus ambalat merupakan konflik bilateral antara Indonesia dan Malaysia. Malaysia memasukkan ambalat kenegaranya pada tahun1979, hingga Indonesia melakukan protes kepada ICJ , namun ICJ membuat keputusan bahwa sipadan dan ligitan menjadi bagian dari Negara Malaysia.

Hasil temuan ke dua yaitu, klasifikasi definisi perbatsan wilayah dalam perspektif Geografi politik, dibedakan menjadi dua yaitu klasifikasi fungsional dan klasifikasi morfologis. Klasifikasi fungsional terdiei dari antesendent boundaries, subsequent boundaries, sumperimposed boundaries, relic boundaries. Dan kalsifiksi morfologis terdiri dari artificial boundaries, natural boundaries.

Berdasrakan paparan di atas dari hasil temuan, penenliti mendeskripsikan tentang klasifikasi definisi perbatasan wilayah dalam prespektif geografi politik sebagai berikut :

a. Klasifikasi fungsional adalah penggolongan perbtasan negara yang berdasrakan sifat relasi di anatra garis perbatasan dan pekembangan bentang lahan budaya (cultural landscape) dari beberapa negra yang dipisah. Klasifikasi fungsional dapat dikategorikan sebagai berikut :

1. Antesedent boundaries yaitu suatu perbatasan yang terbentuk karena negara - negara yang baru ang saling mndahului menetapkan atau memasang suatu batas terluarnya. Jadi terbntuknya suatu perbtsan ini sebelumn terjdinya bentang lahan budaya.

2. Subsequent boundaries yaitu perbatasan yang tertbentuk stelah adanya cultural landscape dan pembuatannya stelah adaaya dasar perundingan dan persetujuan bersama antara kedua negaa yang bersangkutan. Perbatasan ini mengikuti perbedaan etnik kultural khusunya dalam hal bahsa dan agama.

3. Superimposed boundaries, ayitu jenis tipe perbatasan yang proses terbentuknya sama halnya dengan subsequent boundaries namunjenis tipe ini tidak berkaitan dengan pembangian secara sosio kultural. Hal ini disebabkan karena diluar pihak yang smstinya mengadkan perundingan atau sebuah perjanjian yang terdapat kekuatan - kelkuatan lain dari luar yang ikut berkepentingan

4. Relic boundaries yaitu sutau garis perbtasan yang telah hilang fungsi pilitisnya terutama di bidang budayanya. Tipe ini biasanaya terjadi pada suatu negara yang secara sukarela ataupun melalui proses imperialisme mausk ke dalam wilayah negara lain.

5. Klasifikasi morfologis yaitu suatu penggolongan perbatasan negara yang berdasarakan proses terbentuknya. Klasifikasi morfologis di kategorikan menjadi 2 macam yaitu :

1. Artificial boundariesyaitu suatu perbatasan yang tanda batasnya merupakan buatan dari manusia itu sendiri.

2. Natural boundaries yaitu suatu perbatasan yang terbentuk karena sudah proses alamiah. ( Bagus Hermawan, 2017 : 54)

Dari paparan tersebut kasus sengketa pada pulau Sebatik ini merupakan kategori yang berdasarkan morfologis, sebab perbatasan di wilayah pulau Sebatik ini merupaka suatu perbtasan yang tanda batsnya dibuat oleh manusia.

Hasil temuan yang ketiga yaitu, persoalan keamanan tentang sengketa sebatik wilayah perbatasan Indonesia dan Malaysia terdapat 3 ancaman keamanan yaitu pada bidang pertahanan, atau ancaman militer, ancaman ekonomi, dan ancaman ideology. (Chairil, dkk,2019: 35) 


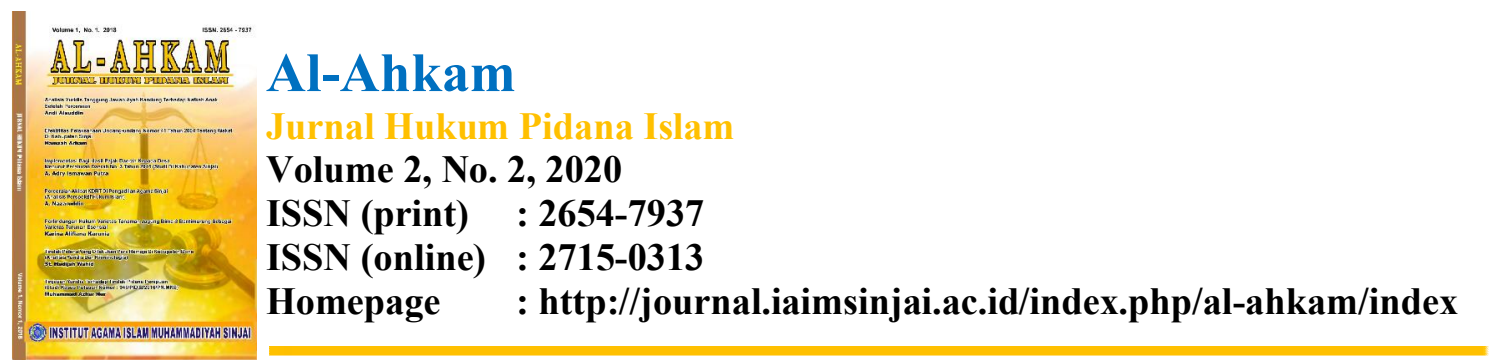

Berdasarkan paparan dari hasil temuan di atas, peneliti mengindetifikasi beberapa masalah tentang keamanan tersebut yaitu :

a. Ancaman keamanan atau pertahanan seperti masih minim nya anggran untuk pengamanan perbatasan, masih kurangnya personil polri yang bertugas di perbatasan, hal tersebut di karena masih adanya jalur tikus, yang menyebab kan adanya penyelundupan narkoba melalui alur tikus diperbatasan Indonesia dan Malaysia. (robeth,2012:55) Para penyelundup biasanya memanfaatkan jalur tikus untuk memasukkan narkoba ke Indonesia. Sulitnya memutus mata rantai penyelundupan narkoba dikarenakan penyelundup dari Malaysia biasanya memilih tempat di wilayah Malaysia, hal mana berakibat tidak dapat dilakukan penangkapan, karena bukan merupakan wilayah tugas dari Kepolisian Republik Indonesia.

b. Ancaman ekonomi , kebutuhan sehaari-hari masih mengandalkan Malaysia. (HasanAbdullah,2013:92) karena jarak dan biaya yang dikeluarkan masyarakat cenderung lebih murah jika dibandingkan dengan membeli barangbarang kebutuhan pokok dari Nunukan. Selain itu, masalah lain yang muncul ialah hal yang berkaitan dengan ketenagakerjaaan.

c. Ancaman ideology, ancaman ideology seperti lunturnya kebanggaan terhadap Indonesia.(Muhammad fakhry,2016: 244) Yang dapat mengikis rasa nasionalisme Indonesia, Desakan kebutuhan ekonomi mendorong para pekerja dari Indonesia untuk berbondong-bondong ke Malaysia, karena secara ekonomi bekerja di perkebunan sawit di Malaysia lebih menggiurkan dibanding bekerja di perkebunan sawit di Indonesia. Penghasilan pekerja Indonesia di Malaysia (Tawau) dihitung dari banyaknya (tonase) buah kelapa sawit yang diambil setiap harinya. Rata-rata pekerja yang bekerja di perkebunan kelapa sawit di Tawau dapat mengantongi uang 350.000-400.000/hari. (Asniwaty,2013:5) Hal ini yang mendorong banyak orang Indonesia berpindah status warga negara menjadi warga negara Malaysia .

Hasil atau temuan yang ke tiga yaitu tentang kasus yang terjadi di pulau sebatik yang sudah mulai terjadi pada tahun 2004 sampai saat ini, dan di pastikan selesai pada tahun 2020. Kasus tersebut pada tahun 2019 sudah ditandai dengan patokan batas yang baru, sehingga patokan yang telah dibuat oleh Belanda dan Ingris di ganti dengan yang sudah dibangun tersebut. Pembangunan patokan tersebut sudah di sepakati oleh kedua negara yaitu Malaysia dan Indonesia secara tehnis. Pilar tersebut dibangun oleh tim direktorat topografi angkatan barat.( Intan Umbari Prihati, 2019). Namun dengan adanya patokan baru tersebut belum memastikan bahwa kasus tersebut sudah terselesaikan. Karena patokan tersebut masih tidak sesuai dengan titik koordinat yang ditentukan. Sehingga sampai saat ini kasus tersebut belum menemukan titik terang yang sebbenarnya. ( Jurnalis, 2019).

Berdasarkan paparan dari hasil temuan diatas, berikut pembahsannya adalah Persoalan ini yaitu mengenai pilar-pilar perbatasan alias patokan batas Negara peninggalan Hindia Belanda dan inggris bahwa garis perbatasan antar Negara akan berada di garis koordinat empat derajat sepuluh menit lintang utara sebagaimana yang sudah di sepakati oleh Hindia Belanda dan Inggris tetapi pada kenyataannya patokan ini sudah tidak sesuai dengan garis koordinat yang sudah di janjikan. Perbatasan yang seharusnya berbentuk garis lurus menjadi berbelok-belok dan berpengaruh pada luas 


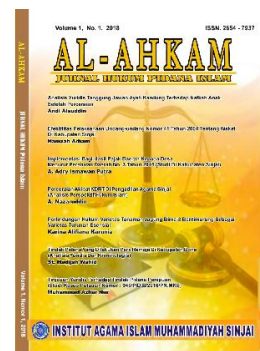

Al-Ahkam

Jurnall Hukum Pidana Islam

Volume 2, No. 2, 2020

ISSN (print) : 2654-7937

ISSN (online) : 2715-0313

Homepage : http://journal.iaimsinjai.ac.id/index.php/al-ahkam/index

wilayah Indonesia dan Malaysia. Setelah adannya kasus tentang patokan di pulau sebatik, Pada tahun 2019 indonesia dan Malaysia sudah sepakat untuk menghancurkan pilar peninggalan Inggris-Belanda dan akan membangun pilar baru yang berada di garis koordina tempat derajat sepuluh menit lintang utara dengan membangun patok perbatasan baru, tetapi kenyataannya kasus yang sudah di sepakati pada tahun 2019 akan di selesaikan kembali pada tahun 2020 saat ini.

Pembahasan mengenai perbatasan pulau sebatik dapat di lihat dari teori Boundary making yang di kemukakan oleh seorang ahli geografi politik Amerika Serikat Sthepen B jones dalam bukunya yang berjudul A Handbookfor Statesmen, Treaty Editors and Boundary Commisioners. Buku tersebut di tulis sebagai suatu buku pegangan atau (handbook) bagi para diplomat, editor perjanjian dan komisioner perbatasan. Buku yang di tulis oleh jones tersebut dalam prakteknya tidak hanya di gunakan oleh para praktisi batas wilayah seperti diplomat, ahli hukum, editor perjanjian, komisioner perbatasan, namun juga oleh para akademisi yang menggeluti masalah batas wilayah. Oleh sebab itu buku dari Stephen A Jones menjadi rujukan penting dan menjadi dan menjadi suatu teori yag di pelajari di lembaga perguruan tinggi yang mendalami ilmu geografi politik dan menjadi pedoman penting di dalam praktek.(Rahman Widiyantoro, 17 : 2016) Stephen B Jones Merumuskan sebuah teori tentang pengelolaan perbatasan suatu Negara yang di bagi menjadi empat tahap utama, dalam pengelolaan perbatasan suatu negara yaitu :

a. Keputusan politik untuk mengalokasi wilayah territorial (Allocation).

b. Delimitasi batas wilayah di dalam perjanjian (delimination).

c. Demarkasi batas wilayah di lapangan (demarcation).

d. Mengadministrasikan batas wilayah (administration).

Penjabaran dari beberapa tahap tersebut yaitu :

a. Alokasi adalah tahap proses politik untuk menentukan pembagian atau alokasi wilayah territorial yang dilakukan pada zaman kolonialisasi, dalam hal ini masing - masing Negara colonial yang akan menguasai wilayah mencapai kesepakatan terhadap pembagian wilayah secara umum. ( Jones, 1945). Pada tahap alokasi ini dihasilkan suatu garis alokasi yang meentukan lingkaran pengaruh atau wilayah yang di kuasainya. Tahap ini tentu saja melibatkan proses dan keputusan politik antara Negara colonial yang tidak mudah. Negara - Negara colonial seperti Inggris, Prancis, Belanda, Spanyol dan Portugis merupakan pencipta garais alokasi. (Part, 2006). Kasus sebatik ini batas wikayah sudah pernah mencapai kesepakatan antara hindia belanda dan inggris, namun seiring berjalannya waktu patokan yang telah dibuat tersebut dinilai telah tidak sesuai dengan qaris koordinat. Terkait dengan persoalan alokasi wilayah perbatasan di kepulauan sebatik, maka pembentukan garis imajiner perbatasan darat antara Indonesia dengan malaysia di pulau Kalimantan adalah di dasarkan pada hasil kreasi para colonial inggris dan belanda pada masa penjajahan. Dalam konteks itu, para colonial membagi garis perbatasan menjadi dua bagian, yaitu : garis perbatasan darat dan garis perbatasan laut(landas kontinen). (Saru Arifin, 193:2009)

b. Delimitasi berarti memilih letak ( site ) suatu garis batas dan mendifinisikannya di dalam perjanjian ( treaty ) atau dokumen formal lainya. Delimitasi adalah suatu tahapan yang lebih teliti di banding tahapan sebelumnya yaitu alokasi, tetapi kurang teliti di banding tahapan sesudahnya yaitu demarkasi. 


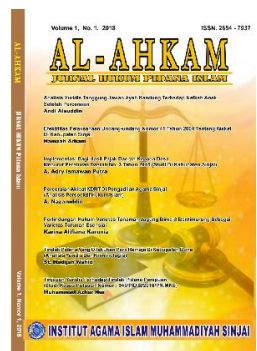

Al-Ahkam

Jurnal Hukum Pidana Islam

Volume 2, No. 2, 2020

ISSN (print) : 2654-7937

ISSN (online) : 2715-0313

Homepage : http://journal.iaimsinjai.ac.id/index.php/al-ahkam/index

Pada kasus sebatik telah terdapat perjanjian antara hindia belanda dan inggris pada masa tersebut. Yang bebentuk patokan sebagai batas wilayah antara Negara Malaysia dan Indonesia. Kesalahan serius terjadi pada tahap delimitasi yaitu ketika memilih letak yang tidak sesuai atau mendifinisikan batas dengan tidak benar pada lokasi yang sudah sesuai. Kesalahan kesalahan tersebut di sebabkan :

1. Tidak mengenali lokasi perbatasan yang akan dipilih.

2. Tidak mengenali dengan baik kekhasan kenampakan geografis yang ada di lokasi perbatasan yang dipilih baik aspek dari alamiah maupun manusinya.

3. Kurangnya pengetahuan terhadap kesulitan - kesulitan di dalam mendefinisikan batas.

Menyusun suatu perjanjian tentang batas wilayah harus teliti dan cermat di dalampenggunaan kata-kata dan memiliki kepastian dan kejelasan hubungan antara yangtertulis di dalam perjanjian dengan kondisi lapangan yang sebenarnya. Bahkanketika peta skala besar tidak tersedia sebagai dokumen, perjanjian tetap harus dapatmenyediakan bahwa tidak ada perbedaan yang besar antara yang tertulis di dalamperjanjian dengan kondisi lapangan pada saat tahap demarkasi selanjutnyadilakukan. Di dalam perjanjian sebaiknya dicantumkan suatu klausal yang memberikekuasaan kepada komisi demarkasi batas untuk melakukan atau memberirekomendasi penyesuaian (adjusment) garis batas di lapangan bila diperlukan. Inimenjadi catatan penting bahwa sebenarnya tidak ada pendefinisian batas di dalamperjanjian yang tidak dapat dibatalkan sampai suatu tim teknis yang berpengalamandalam permasalahan perbatasan dimintai pendapat tentang pemilihan letak garisbatas dan merumuskannya definisi batas tersebut di dalam bentuk kata-kata ataukalimat.Hal tersebut sebenarnya menjadi suatu catatan penting bahwa masukan hasil surveylapangan sangat diperlukan sebelum memilih dan mendefiniskan batas wilayah.Survey lapangan sebenarnya tidak memerlukan waktu lama,Namun hasilnya sangat membantu untuk menghindari ketidak tepatan pemilhan lokasi dan menghindari ketidak akuratan pendefinisian garis batas. Penyelesaian sengketa dapat di selesaikan oleh mahkamah internasional, maka dari itu kesepatan penentuan garis antara Indonesia dan Malaysia di pulau Kalimantan dari Tanjung datu di Kalimantan barat sampai Kalimantan timur sepanjang 2004 meter.

c. Demarkasi adalah aplikasi final dan menandai batas dilapangan. Demarkasi adalah lebih pada proses mekanis dibandingkan delimitasi yang mencangkup pendirian beacon atau pilar tanda pemberian nomor dan mencatat tanda tanda tersebut kedalam peta . kegiatan demarkasi batas meruapakan bentuk kegiatan tehnis terakhir dari rangkaian penentuan dan penataan batas suatu daerah. Tanda ataupun batas pada kasus sebatik telah ditentukan pada tahun 2019 sebagai langkah pertama penyelesaian batas wilayah tersebut. Dengan didirikannya patokan atau pilar baru pada daerah sebatik. Yang kemudian akan diselesaikan pada tahun 2020.

d. Administrasi batas daerah adalah kegiatan mengurus dan memelihara keberadaan batas daerah. Implementasinya antara lain adalah menjadikan batas daerah dibuatkan produk hukum, kemudian menciptakan situasi yang kondusif di perbatasan. Hal ini tentu saja terkait aktifitas sosial budaya, 


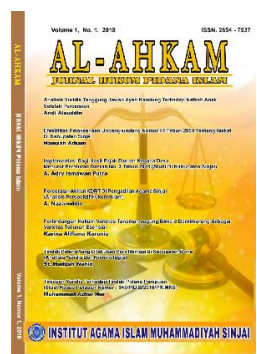

Al-Ahkam

Jurnall Hukum Pidana Islam

Volume 2, No. 2, 2020

ISSN (print) : 2654-7937

ISSN (online) : 2715-0313

Homepage : http://journal.iaimsinjai.ac.id/index.php/al-ahkam/index

pelayan publik, lingkungan dan terutama ekonomi untuk kesejahteraan masyarakatnya, dll.

Merujuk pada teori yang dikemukakan oleh James di atas, secara garis besar isu utama yang terjadi di wilayah perbatasan antar negara yaitu :

1. Penetapan garis batas baik darat maupun laut

2. Pengamanan kawasan perbatasan

3. Pengembangan kawasan perbatasan.

Dalam konteks pengelolaan perbatasan negara Indonesia masih memiliki persoalan dalam ketiga isu utama tersebut. Yang salah satunya yaitu kasus pulau Sebatik. Yang mana kasus pulauSebatik ini masih belum diaplikasikan pada kehidupan, hal tersebut dikarenakan kedua Negara tersebut belum sepenuhnya dapat menyelsaikan atau pun belum menentukan batas wilayah secara konkrit, hanya saja langkah awal penyelesaiannya dengan membuat patokan sementara yang nantinya akan diselesaikan pada tahun 2020. Sehingga untuk membuat produk hukum untuk menciptakan aktivitas sosial, budaya, dll masih belum berjaln dengan posistif, hanya aja ada beberapa kegiatan yg dirasa memiliki dampak negative seperti adanya penyelundupan narkoba.

Hasil atau temuan yang ke lima yaitu setelah pembangunan patokan di wilayah sebatik, ada bebrapa program pembangunan pada kawasan perbatasan di pulau sebatik, program yang di bahas dalam bagian ini, yaitu isu pembangunan kawasan perbatasan, strategi pembangunan, kebijakan serta program yang di laksanakan, kinerja pembangunan kawasan perbatasan dan rencana pembangunan perbatasan dalam jangka menengah.

a. Isu pembangunan kawasan perbatasan , Kawasan perbatasan, termasuk pulau-pulau kecil terluar, memiliki potensi sumber daya alam(SDA) yang sangat besar yang dapat di optimalkan pemanfaatannya untuk untuk meningkatkan pertumbuhan perekonomian daerah dan peningkatan kesejahteraan masyarakat. Selain itu, kawasan perbatasan merupakan kawasan yang sangat strategis bagi perhatanan dan keamanan Negara.

Permasalahan lain yang tidak dapat di lepaskan dalam pengelolaan kawasan perbatasan adalah belum di sepakatinya penetapan wilayah Negara di beberapa segmen batas darat dan laut melalui kesepakatan dengan Negara tetangga.kerusakan atau pergeseran sebagian patok-patok batas darat sering menyebabkan demarkasi batas di lapangan menjadi kabur. ( Baskoro Wicaksono, 2019)

Terdapat permasalahan serius yang terdapat di daerah perbatasan du kepulauan sebatik antara lain:

a) Belum terintegrasinya pengelolaan sumber daya alam, khususnya wilayah lindung dan konservasi hutan, lintas Negara dalam program kerjasama bilateral antara Indonesiamalaysia mengakibatkan perbedaan penggunaan lahan perbatasan antara kedua Negara.

b) Berbagai peristiwa-peristiwa baik yang terkait dengan aspek keamanan dan politis, maupun pelanggaran dalam pengelolaan dan ekspoitasi sumberdaya alam lintas batas Negara, baik sumber daya alam darat maupun laut telah mengakibatkan timbulnya masalah atau gangguan hubungan bilateral antar Negara.

c) Pemekaran wilayah yang tidak diikuti dengan kesiapan sarana dan prasarana serta aparatnya.(Farouk Ishak, dkk. : 2003)

Dalam permasalahan di atas maka terdapat pengaruh yang besar terhadap pembangunan perbatasan yang sudah di bangun pada tahun 2019, dalam permasalahan ini maka pemerintah juga harus ikut andil dalam permasalahan setelah pembangunan patokan oleh Negara Indonesia-malaysia.

b. Kebijakan pemerintah provinsi Kalimantan timur dalam pembangunan kawasan perbatasan. 


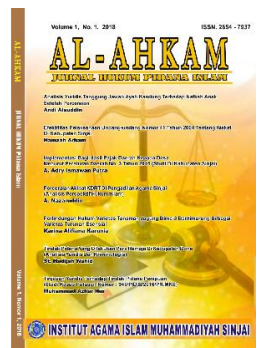

Al-Ahkam

Jurnal Hukum Pidana Islam

Volume 2, No. 2, 2020

ISSN (print) : 2654-7937

ISSN (online) : 2715-0313

Homepage : http://journal.iaimsinjai.ac.id/index.php/al-ahkam/index

Perbatasan merupakan kawasan strategis karena letaknya yang langsung berhadapan dengan wilayah lainnya, tetapi potensi yang sangat besar ini belum di manfaatkan secara optimal, sehingga wilayah perbatasan tergolong dalam kawasan tertinggal, terisolir dan belum berkembang.(Sonny Sudiar ,2012:395)

Dalam kebijakan pembangunan daerah perbatasan suatu Negara harus melakukan antara lain:

1. Rancangan pembangunan jangka panjang

Rancangan pembangunan jangka panjang (RPJPN) adalah dokumen perencanaan pembangunan nasional untuk periode 20 tahun. RJPN nasional untuk tahun 20052025 di atur dalam undang-undang nomor 17 tahun 2007. Dalam pembangunan nasional dalam pasal undang-undang harus melihat dalam: pembangunan politik, pembangunan pertahanan dan keamanan, pembangunan hukum dan penyelenggaraan Negara, pembangunan sosial budaya, pembangunan sumber daya manusia, ekonomi, daerah, infrastuktur. ( BPPN: 2005)

2. Rancangan pembangunan jangka menengah

Rencana pembangunan jangka menengah nasional merupakan bagian dari rencana pembangunan jangka panjang nasional yang berkedudukan sebagai dokumen perencanaan induk, di mana acuan utama memuat visi, misi, arah kebijakan dan rencana program indikatif kepala pemerintahan terkait dengan rancangan pembangunan secara nasional yang akan di jadikan pedoman dalam penyusunan rencana kerja daerah .(Sonny sudiar,2012:396)

Kasus yang terjadi pada kepulauan sebatik ini adalah kasus tentang persengketaan antara Negara Indonesia dan Malaysia yang memperebutkan batas wilayah Negara Indonesia dan Malaysia. Kasus ini sudah terjadi dari tahun 1967 dari kasus pulau ligitan dan sipadan, kasus pulau ambalat, dan kepulauan sebatik. Penyebab terjadinya persengketaan kepulauan sebatik ini yaitu tidak sesuainya sebuah patokan yang sudah di sepakati oleh hindia belanda dan inggris yang sudah membuat sebuah perjanjian tentang batas wilayah. Perjanjian ini berisi tentang patokan yang sudah di janjikan oleh hindia belanda dan inggris, bahwa garis perbatasan antar Negara akan berada di garis koordinat empat derajat sepuluh menit lintang utara. tetapi pada kenyataannya patokan ini sudah tidak sesuai dengan garis koordinat yang sudah di janjikan. Perbatasan yang seharusnya berbentuk garis lurus menjadi berbelok-belok dan berpengaruh pada luas wilayah Indonesia dan Malaysia. Pada tahun 2019 negara Indonesia dan Malaysia merubah perjanjian yang sudah di sepakati oleh hindia belanda dan inggris. Cara untuk menyelesaikan persengketaan ini Negara Indonesia dan Negara Malaysia sepakat untuk membangun patokan perbatasan baru, tetapi pada kenyataannya kasus ini belum terselesaikan karena adanya ancaman keamanan bagi Negara Indonesia, dan rencananya kasus ini akan di selesaikan pada tahun 2020 saat ini. Dalam menanggulangi kasus perbatasan di pulau Sebatik ini Upaya pemerintah salah satunya yaitu melakukan renacana pembangunan jangka panjang dan rencana pembangunan jangka menengah. Karena Perbatasan merupakan kawasan strategis yang letaknya secara langsung berhadapan dengan wilayah negara lainnya. Dengan adanya upaya pemerintah ini diharpkan dapat mengatasi permasalahan yang terjadi di kawasan perbatasan antara Indonesia dan Malaysia. 


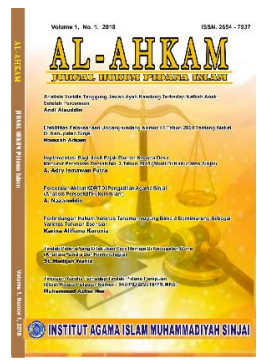

Al-Ahkam

Jurnal Hukum Pidana Islam

Volume 2, No. 2, 2020

ISSN (print) : 2654-7937

ISSN (online) : 2715-0313

Homepage : http://journal.iaimsinjai.ac.id/index.php/al-ahkam/index

\section{Daftar Pustaka}

Baskoro Wicaksono, 2015. Penguatan wilayah perbatasan: Studi Kasus Pulau Sebatik Kabupaten Nunukan Provinsi Kalimantan Timur. Diakses dari https://www.researchgate.net/publication/340604646_penguatan_wilayah_perbatas an_Studi_Kasus_pulau_Sebatik_Kabupaten_Nunukan_Provinsi_Kalimantan_Timu $\underline{r}$

Budi Hermawan, 2017. Konsepsi dan pengelolaan wilayah perbatasan negara: prespektif hukum internasional. Tanjungpuro Law Jurnal. 1 (1). Diakses dari http://jurnal.untan.ac.id/index.php/tlj

Purnawan Basundoro, 2013. Pulau sebatik sebagai pintu kecil hubungan Indonesia dan Malaysia. Fakultas ilmu budaya universitas airlangga. Jurnal Literasi. 3 (2). Diakses dari https://jurnal.unej.ac.id/index.php/LIT/article/view/6121

Rahman Widiantoro. 2016. Penyelesaian Persoalan Batas Daerah Antara Jabupaten Gunungkidul Dengan Kabupaten Bantul. Fakultas Syariah Dan Hukum Universitas Islam Negeri Sunan Kalijaga Yogyakarta. Diakses dari http://digilib.uin.suka.ac.id/21634/1/11340139_BAB-I_IV-atau-V_DAFTARPUSTAKA.pdf

Robeth Siburian,2012.Pulau sebatik kawasan perbatasan Indonesia beraroma Malaysia. Jurnal masyarakat dan budaya. 14 (1). Diakses dari http://jmb.lipi.go.id/index.php/jmb/article/download/87/86

Saru Arifin. 2009. Pelaksanaan Asas Uti Possidetis Dalam Penentuan Titik Patok Perbatasan Darat Indonesia Dengan Malaysia. Jurnal Hukum. 16 (2). Diakses dari https://www.neliti.com/id/pub;icatioms/80914/pelaksanaan-asas-uti-possidetisdalam-penentuan-titik-patok-perbatasan-darat-ind

Sonny Saudiar, 2012. Kebijakan pembangunan perbatasan dan kesejahteraan masyarakat di wilayah perbatasan pulau sebatik, Indonesia. Jurnal Paradigma. 1 (3). Diakses dari http://e-journals.umul.ac.id/index.php/Jparadigma/article/download/316/279

Zulkifli Rahmat, 2014. Peran Korem 091/ Aji Surya Natakusuma dalam Keamanan wilayah perbatasan Indonesia dengan Malaysia di Pulau Sebatik Kabupaten Nunukan Provinsi Kalimantan Timur. eJurnal Ilmu Pemerintah. 2 (4). Diakses dari https://ejournal.ip.fisip-unmuh.ac.id/site/wpcontent/uploads/2014/12/ejournal\%20(PDF)\%20(12-05-14-12-26-00).pdf 